\title{
Tobacco and Europe: Britain against the rest
}

\author{
Britain does the tobacco industry's job in Brussels
}

The blaze of publicity given to last week's failure of British health minister Kenneth Clarke to sabotage the European plan to strengthen the health warning on tobacco packaging has focused unprecedented attention on the Europe Against Cancer programme. In 1985 the European Council of Ministers agreed on common action against cancer, and the resulting programme is run by the European Commission. It contains a range of preventive measures-including health education, training, research, and proposed legislationaimed particularly at reducing tobacco consumption and at improving nutrition.' As recently as January this year Mrs Thatcher gave the campaign her full backing.

The proposed legislation on tobacco drafted by the commission in close consultation with the 12 governments includes four directives: strengthening the health warning on tobacco packaging; limiting tar yields of cigarettes to $15 \mathrm{mg}$ by 1992 and $12 \mathrm{mg}$ by 1995; restricting tobacco advertising (including a ban on indirect advertising) ${ }^{2}$; and protecting children against the sale of tobacco products. A directive once approved by the council must be incorporated into the laws of member states. A fifth measure-to restrict smoking in public places-has been weakened to a non-binding recommendation.

The directive on health warnings was adopted by the council last week despite opposition from Mrs Thatcher and Mr Clarke. Mr Clarke failed because the other 11 health ministers voted for the directive-and did so in obvious impatience with the British attitude.

Mrs Thatcher approved the Europe Against Cancer programme and signed the Single European Act 1987. Why is she now obstructing measures that flow directly from them? The government claims that Britain's opposition arises from concern about constitutional issues. Mrs Thatcher has set her face against Brussels bureaucracy and any extension of its powers over sovereign governments or subjects beyond its competence. But is this just a convenient smoke screen?

It is true that the Treaty of Rome (which established the community) and the Single European Act (designed to remove trade barriers by 1992) say nothing about health. One ploy used by Britain has thus been to question the community's right to bring in health measures, arguing that health policy should be handled nationally. But the single act includes an obligation to take health protection into account in framing legislation. Furthermore, harmonised packet labelling (which includes the health warning) is clearly necessary for free movement of goods in the community and is thus covered by the act.

Having been defeated on these points in the council, $\mathrm{Mr}$ Clarke tried a different tack afterwards. He complained that the community should not decide in such detail what individual countries do and that Britain was capable of designing strong health warnings. He added that Britain had a better record than other European countries in these matters. This is misleading. It is precisely because the British government has voluntary agreements with the tobacco industry that the health warning is so weak. The industry would never have agreed to the tough warnings proposed by the commission. It is also misleading as the European directive does not prevent individual countries from pursuing tougher additional measures.

The remaining official explanation for Britain's opposition to these health measures is Mrs Thatcher's opposition to Brussels usurping the power of sovereign states. This is nonsense. Mrs Thatcher has portrayed the commission as an imperialistic interfering bureaucracy. In fact it is simply the administrative arm of the community. Final decisions are made by the Council of Ministers - that is, by Mrs Thatcher and her 11 counterparts.

When European legislation has been useful for passing approved trade measures the government has acquiesced. It obstructs when it disapproves of the measures themselves. What we are seeing therefore is the government's opposition to the prevention of smoking (and its support of the tobacco industry) disguised as anti-European sentiment. In view of Mrs Thatcher's personal support of the launch of Europe Against Cancer this is breathtaking hypocrisy. The European Commission expected a rough ride for the tobacco directives from the tobacco industry. It had not expected the British government to do the industry's job for it.

MARTIN RAW

Research Fellow,

King's College School of Medicine and Dentistry,

London SE5 9PJ

1 European Communities. Europe against cancer programme. Official fournal of the European Communities 1987 February 26;30:1-64. (Series 650.) 2 Raw M. What is a cigarette ad? Br Med $\mathcal{F} 1989 ; 298: 1133$. 